\title{
KEDUDUKAN JAMINAN DAN DENDA PADA PEMBIAYAAN \\ BANK SYARIAH
}

\author{
Nonie Afrianty \\ IAIN Bengkulu \\ Email:noni@iainbengkulu.ac.id
}

\begin{abstract}
Islamic banking has a role as an intermediary institution that is an intermediary between savers and investors and banks to function as an agent of development. In funds, Islamic banks must provide the requirements that must be met by the customer (debtor), one of which is the guarantee and in the event of late payment by the customer, will be fined. However, in reality there are many financing that does not run smoothly. Islamic bank collateral position is as an application of the precautionary principle and the prudential banking bank or a fine position in Islamic banks are based on the principle ta'zir which aims to enable customers to be more disciplined in carrying out its obligations. The funds raised from fines is intended for charity
\end{abstract}

Keywords: financing, guarantees, penalties

Abstrak: Perbankan syariah memiliki peran sebagai lembaga intermediasi yakni perantara antar penabung serta investor dan bank berfungsi sebagai agen of development. Dalam menyalurkan dana, bank syariah harus memberikan persyaratan yang wajib dipenuhi oleh nasabah (debitur) yang salah satunya adalah jaminan dan jika terjadi keterlambatan pembayaran oleh nasabah, akan dikenakan sanksi denda. Akan tetapi, pada kenyataannya masih banyak pembiayaan yang tidak berjalan dengan lancar. kedudukan jaminan pada bank syariah adalah sebagai penerapan prinsip kehati-hatian bank atau prudential banking dan kedudukan denda pada bank syariah adalah didasarkan pada prinsip ta'zir yang bertujuan agar nasabah lebih disiplin dalam melaksanakan kewajibannya. Dana yang berasal dari denda ini diperuntukan untuk dana sosial

Kata Kunci: pembiayaan, jaminan, denda

\section{A. PENDAHULUAN}

Perkembangan perbankan syariah di Indonesia dari tahun ke tahun semakin meningkat yang telah tersebar diberbagai plosok tanah air. Hal ini di latar belakangi oleh fungsi dasar yang dimiliki oleh lembaga keuangan syariah (LKS) yaitu menghimpun kelebihan dana dari masyarakat dan menyalurkan dana kepada masyarakat yang kekurangan dana dengan menjual produk-produk serta akad yang sesuai dengan yang telah ditetapkan oleh Dewan Pengawas syariah (DPS) yang bertugas mengawasi kegiatan operasional kegiatan LKS sesuai dengan kententuan-kententuan syariah atau dapat disebut bank sebagai financial intermediaries yakni perantara antar penabung serta investor dan bank berfungsi sebagai agen of development (pelaksana tugas bank dikaitkan dengan tujuan pembangunan dan pemerataan.) ${ }^{1}$

$$
\text { Dalam menjalankan perannya }
$$
sebagai lembaga intermediasi sebagai lembaga keuangan menyalurkan dana kepada pihak yang membutuhkan dengan tujuan pemerataan dan pembangunan, bank syariah dalam hal ini harus memberikan persyaratan yang wajib dipenuhi oleh nasabah (debitur). Pembiayaan merupakan bagian aset yang tergolong besar dari bank syariah sehingga pembiayaan harus dijaga kualitasnya, maka dari itu berdasarkan pasal 35 ayat 1 Undang-undang No.21

${ }^{1}$ Gemala Dewi, Aspek-Aspek Hukum dalam Perbankan dan Perasuransian Syariah di Indonesia, Cet.IV, (Jakarta:Kencana, 2007), hlm, 55 
tahun 2008 tentang perbankan syariah, maka jaminan merupakan esensi yang harus ada sebagai penerapan prinsip kehati-hatian bank atau Prudential banking.

Sebelum menyalurkan pembiayaan atau menyalurkan dana kepada nasabah, bank syariah terlebih dahulu melakukan penilaian terhadap nasabah yang menunjukkan bahwa nasabah mempunyai kemampuan dan kemauan untuk melunasi fasilitas pembiayaan yang mereka terima. Akan tetapi, pada kenyataan masih banyak pembiayaan yang tidak berjalan dengan lancar yang disebabkan oleh nasabah yang sengaja tidak memenuhi kewajibannya padahal mampu atau bahkan mengalami kemunduran dalam usahanya sehingga tidak mampu untuk memenuhi kewajibannya pada bank. Apabila terjadi keterlambatan dalam memenuhi kewajibannya pada bank, nasabah dikenakan denda yang telah ditentukan pada saat penandatanganan akad. Berdasarkan pemaparan di atas, tulisan ini akan menjelaskan bagaimana kedudukan jaminan dan denda pada perbankan syariah.

\section{B. PEMBIAYAAN}

Dalam kamus perbankan, konsep yang dimaksud biaya adalah pengeluaran atau pengobatan yang tidak terhindarkan untuk mendapatan barang atau jasa dengan tujuan memperoleh maslahat pengiriman, pengepakan atau penjualan, dimaksudkan untuk memperoleh penghasilan dalam laporan laba rugi, komponen biaya merupakan mengurang dari pendapatan. Pengertian biaya berbeda dengan beban, semua biaya adalah beban tetapi tidak semua beban adalah biaya. ${ }^{2}$

Pembiayaan (financing) merupakan istilah yang digunakan dalam bank syariah, sebagaimana dalam bank konvensional disebut dengan kredit (lending). ${ }^{3}$ Pembiayaan merupakan salah satu tugas pokok bank syariah yaitu memberikan fasilitas penyediaan dana untuk memenuhi kebutuhan pihak-pihak yang merupakan defisit unit. ${ }^{4}$

Pengertian pembiayaan menurut Undang-Undang Perbankan Nomor 10 Tahun 1998 ayat 12 berbunyi:

Penyediaan uang atau tagihan yang dapat dipersamakan berdasarkan persetujuan atau kesepakatan antara bank dengan pihak lain yang mewajibkan pihak yang dibiayai untuk mengembalikan uang atau tagihan tersebut setelah jangka waktu yang tertentu dengan imbalan atau bagi hasil. $^{5}$

\footnotetext{
${ }^{2}$ Bank Indonesia, Kamus Perbankan, 1999, Cet ke-1, hlm .30

${ }^{3}$ Ahmad Dahlan, Bank Syariah Teoritik Praktik Kritik, (Yogyakarta:Teras, 2012), hlm. 162

${ }^{4}$ Habib Nazir, Muhammad Hasanuddin, Ensiklopedi Ekonomi dan Perbankan Syariah, (Bandung: Kafa Publishing, 2008), hlm. 516

${ }^{5}$ Undang-Undang Perbankan No.10 Thn 1998, (Jakarta: Sinar Grafika, 2001), Cet ke-1, hlm. 30
} 
Dalam pasal 1 angka 25 Undangundang No.21 Tahun 2008 tentang perbankan syariah disebutkan:

Pembiayaan adalah penyediaan dana atau tagihan yang dipersamakan dengan itu berupa:

1. Transaksi bagi hasil dalam bentuk mudharabah dan musyarakah;

2. Transaksi sewa-menyewa dalam bentuk ijarah atau sewa beli dalam bentuk ijarah muntahiya bittamlik;

3. Transaksi jual beli dalam bentuk piutang murabahah, salam dan istishna';

4. Transaksi pinjam meminjam dalam bentuk piutang qardh; dan

5. Transaksi sewa menyewa jasa dalam bentuk ijarah untuk transaksi multijasa berdasarkan persetujuan atau kesepakatan antara bank syariah yang mewajibkan pihak yang dibiayai untuk mengembalikan dana tersebut setelah jangka waktu tertentu dengan imbalan ujrah, tanpa imbalan atau bagi hasil. ${ }^{6}$

Secara mikro pembiayaan memiliki tujuan sebagai berikut:

1. Upaya memaksimumkan laba, artinya: setiap usaha yang dibuka memiliki tujuan tertinggi, yaitu menghasilkan laba usaha.

2. Pendayagunaan sumber ekonomi, artinya sumber daya ekonomi dapat dikembalikan dengan melakukan mixing

${ }^{6}$ Ahmad Dahlan, Bank ..., hlm. 162 antara sumber daya alam dengan sumber daya manusia serta sumber daya modal.

3. Penyaluran kelebihan dna, artinya dalam kehidupan masyarakat ada pihak yang memiliki kelebihan semenstara yang lain ada pihak yang kekurangan. Dalam kaitannya dengan masalah dana, maka menisme pembiayaan dapat menjadi jembatan dalam penyeimbangan dan penyaluran kelebihan dana dari pihak yang kelebihan (surplus) kepada pihak yang kekurangan (minus) dana. ${ }^{7}$

Orang yang mendapatkan pembiayaan dari bank adalah orang yang dipercaya, orang tersebut dinilai akan mampu dan mau untuk mengembalikan fasilitas pembiayaan yang diberikan oleh bank syariah. Untuk mengetahui dan menentukan bahwa seseorang dipercaya untuk memperoleh pembSiayaan dengan menggunakan instrumen analisa yang dikenal dengan the fives of credits atau 5C, yakni:

1. Character (watak)

Pertimbangan utama dalam proses pembiayaan, meskipun analisa dari berbagai aspek baik tetapi watak seorang pemohon jelek maka resiko pembiayaan akan menjadi besar. $^{8}$

${ }^{7}$ Muhammad, Manajemen Pembiayaan Bank Syariah, (Yogyakarat: UPP AMP YKPN, 2005), hlm. 17

${ }^{8}$ Sutarno, Aspek-Aspek Hukum Perkreditan Pada Bank, (Bandung: Alfabeta, 2005), hlm. 93 
Informasi ini dapar dikumpulkan dari berbagai pihak di lingkungan tempat tinggal, pergaulan atau data dari lembaga pembiayaan lainnya. ${ }^{9}$

2. Capital (modal)

Seseorang atau badan usaha yang akan menjalankan usaha atau bisnis sangat memerlukan modal untuk memperlancar kegiatan bisnisnya. Pemohon pembiayaan yang berbentuk badan usaha, besarnya modal yang dimiliki pemohon pembiayaan ini dapat dicermati dari laporan keuangan. Semakin besar jumlah modal yang dimiliki maka menunjukkan perusahaan tersebut memiliki kemampuan untuk memenuhi kewajiban membayar hutangnya.

3. Capacity (kemampuan)

Untuk dapat memenuhi kewajiban pembayaran debitur harus memiliki kemampuan memadai yang berasal dari pendapatan pribadi jika debitur perorangan atau pendapatan perusahaan bila berbentuk badan usaha.

4. Collateral (jaminan)

Berfungsi meberikan hak dan kekuasaan kepada bank untuk mendapatkan pelunasan dari barangbarang jaminan tersebut bilamana debitur tidak dapat melunasi hutangnya

${ }^{9}$ Muchdarsyah Sinungun, Manajemen Dana Bank ed II, (Jakarta:PT.Bumi Aksara, 2000), hlm. 242 pada waktu yang ditentukan dalam perjanjian. $^{10}$

5. Condition of Economy (kondisi ekonomi)

Kondisi dan situasi ekonomi yang berkatan erat dengan usaha yang dijalankan oleh nasabah baik dalam skala mikro maupun makro. ${ }^{11}$

Selain penerapan $5 \mathrm{C}$, penerapan $5 \mathrm{P}$ juga diperlukan yang diantaranya adalah:

1. Party (golongan) adalah mencoba menggolongkan calon nasabah pembiayaan kedalam kelompok tertentu menurut character, capacity dan capitalnya.

2. Purpose (tujuan) adalah penggunaan pembiayaan yang diajukan sesuai dengan tujuan yang sebenarnya.

3. Payment adalah kemampuan dan kekuatan calon nasabah pembiayaan untuk membayar kembali pembiayaan yang diberikan sekaligus cara dan jangka waktu pembiayaannya.

4. Profitability atau kemampuan mendapatkan keuntungan ; yang dimaksud adalah bukan hanya keuntungan yang diperoleh nasabah dari usahanya melainkan juga keuntungan yang akan didapatkan oleh bank apabila nasabah tersebut menggunakan fasilitas lain di bank tersebut.
${ }^{10}$ Sutarno, Aspek...., hlm. 93-94

${ }^{11}$ Muchdarsyah Sinungun, Manajemen Dana Bank ed II, (Jakarta:PT.Bumi Aksara, 2000), hlm. 242 
5. Protection yaitu perlindungan terhadap pembiayaan dengan meminta jaminan dan asuransi. ${ }^{12}$

Dalam pembiayaan juga diperlukan analisa dari faktor eksternal dari usaha calon nasabah antara lain:

1. Tren usaha artinya penilaian usaha yang akan dibiayai dianalisa dengan mengetahui kondisi makro usaha tersebut atau tren usaha yang sedang berkembang.

2. Peluang bisnis artinya sejauh mana usaha calon nasabah pembiayaan dapat berkembang dan menghasilkan keuntungan atau pendapatan bagi nasabah.

3. Reputasi bisnis perusahaan, poin ini diperlukan untuk mengetahui sejauh mana kredibilitas usaha calon nasabah serta pengalaman usaha calon nasabah.

4. Reputasi manajemen; reputasi manajemen yang baik akan menjadikan usaha calon nasabah dapat berkembang dengan maksimal dan memperkuat penilaian terhadap kredibilitas perusahaan. ${ }^{13}$

Dalam berinvestasi bank syariah memiliki prinsip untuk tidak pernah merugi, dan kemungkinan tersebut tidak akan terjadi selama bank tidak ikut menanggung kerugian yang dialami oleh

\footnotetext{
${ }^{12}$ Hermansyah, Hukum Perbankan Nasional Indonesia, (Jakarta:Kencana, 2005), hlm. 59

${ }^{13}$ Sunarto Zulkifli, Panduan Praktis Transaksi Perbankan Syariah, (Jakarta: Zikrul Hakim, 2003), hlm. 139
}

nasabahnya (commanditeringsverbod). Commanditeringsverbod yaitu adanya larangan bagi bank untuk menanggung risiko dan kerugian dari usaha nasabah. Commanditeringsverbod ini merupakan ketentuan yang berlaku di bank umum konvensional, karena bank tidak boleh merugi, sehingga semua risiko bisnis nasabah ditanggung sendiri dan nasabah itu tetap memiliki kewajiban untuk membayar kredit yang telah diperoleh dari bank. ${ }^{14}$

Bila bank harus menghadapi kerugian ada beberapa masalah yang akan terjadi, yaitu nasabah kreditur berinvestasi pada bank syariah dengan tujuan untuk mendapatkan keuntungan semaksimal mungkin dari setiap dana yang mereka miliki dan telah dipercaya kepada bank untuk dikelola.

Secara garis besar akad pada bank syariah yaitu NCC dan NUCC. Risiko yang muncul dominan pada pembiayaan dengan mengunakan pembentukan akad dengan menggunakan pola NUCC seperti musyarakah dan mudharabah adalah mengidentifikasi, menilai, mengukur risiko dari seluruh risiko yang memiliki kemungkinan dilakukan nasabah debiturnya. Dengan adanya penerapan manajemen risiko yang baik terhadap pembiayaan nasabah debitur, maka manajemen bank syariah dapat membuat

\footnotetext{
${ }^{14}$ Sri Soedewi Sofyan, Hukum Jaminan di Indonesia Pokok-Pokok Hukum Jaminan dan Jaminan Perorangan, Cet.Ketiga, (Yogyakarta: Liberty Offset, 2003), hlm.46
} 
keputusan yang tepat untuk mengucurkan pembiayaan atau tidak.

Analisis risiko pada setiap aktivitas pembiayaan mudharabah dan musyarakah menjadi suatu kemestian supaya aktivitas pembiayaan memiliki feed back positif bagi bank dan nasabah juga. Analisis risiko yang dilakukan harus sistematis dan jeli dengan meliputi 3 aspek penting yang melekat pada kedua jenis pembiayaan ini, yaitu:

1. Business risk yang diberikan pembiayaan melalui akad musyarakah dan mudharabah. Risiko yang muncul cenderung berkaitan dengan first way out, yang dipengaruhi oleh:
a. Risiko industri;
b. Market risk;
c. Restrukturisasi pembiayaan;
d. Keadaan force majeure, dan lain- lain.

2. Shrinking risk yang muncul dengan berkurangnya nilai pembiayaan yang terjadi pada second way out yang dipengaruhi oleh : Unusual business risk dan sistem bagi hasil yang dipilih.

3. Disaster risk.

\section{JAMINAN (Dhaman)}

\section{Pengertian Jaminan}

Jaminan (Dhaman) adalah harta yang ditempatkan sebagai anggunan untuk pembayaran atau kesanggupan atas suatu kewajiban. ${ }^{15}$ Jaminan memiliki bentuk yang akan dapat dijadikan bentuk akad dasar landasan yaitu Rahn ${ }^{16}$, yang mana merupakan kegiatan menahan salah satu harta milik si peminjam sebagai jaminan atas peminjaman yang diterimanya. ${ }^{17}$ Berdasarkan DSN No. 68/DSNMUI/III/2008 tentang rahn tasjily, dimana rahn tasjily adalah jaminan dalam bentuk barang atas utang tetapi barang jaminan tersebut (marhun) tetap berada dalam penguasaan (pemanfaatan) Rahin dan bukti kepemilikannya diserahkan kepada murtahin. Daman mengandung tiga permasalahan, yaitu :

a. Jaminan atas utang seseorang, misal A menjamin utang B kepada $\mathrm{C}$, maka $\mathrm{C}$ boleh menagih piutangnya kepada A atau kepada B;

b. Jaminan dalam pengadaan barang, misal A menjamin mengembalikan barang yang dipinjam oleh $\mathrm{B}$ dari $\mathrm{C}$. Apabila B tidak mengembalikan barang itu kepada $\mathrm{C}$ maka $\mathrm{A}$ wajib mengembalikannya kepada $C$;

c. Jaminan dalam menghadirkan seseorang di tempat tertentu,

\footnotetext{
${ }^{15}$ Ahmad Ifham Sholihin, Buku Pintar Ekonomi Syariah, (Jakarta: PT.Gramedia Pustaka Utama, 2010), hlm. 366

${ }^{16}$ Nasrun Haroen, Fiqh Muamalah, (Jakarta: Gaya Media Pratama, 2007), hlm. 251

${ }^{17}$ Kasmir, Bank dan Lembaga Keuangan lainnya. Edisi Revisi, (Jakarta: PT.Raja Grafindo Persada, 2008), hlm. 200
} 
misalnya A menjamin menghadirkan

B yang sedang dalam perkara ke muka pengadilan pada waktu dan tempat yang telah ditentukan. ${ }^{18}$

Pembiayaan yang diberikan oleh bank banyak mengandung resiko, sehingga bank dalam pelaksanaannya harus memperhatikan asas-asas kehatihatian dalam pembiayaan. Guna mengurangi resiko kerugian dalam pemberian pembiayaan maka diperlukan jaminan inilah yang harus diperhatikan oleh bank. Maka keberadaan jaminan diatur dalam pasal 8 UU Perbankan 1992 ditentukan bahwa:

"dalam memberikan kredit, Bank umum wajib mempunyai keyakinan atas kemampuan dan kesanggupan debitur untuk melunasi hutangnya sesuai yang diperjanjikan"19

Di dalam Undang-Undang Nomor

21 Tahun 2008 tentang perbankan syariah digunakan istilah anggunan untuk memaknai suatu jaminan, baik berupa benda bergerak maupun benda tidak bergerak yang diserahkan oleh pemilik angguna kepada bank, dalam rangka pemberian fasilitas pembiayaan

${ }^{18}$ Abdul Aziz Dahlan, Ensiklopedi Hukum Islam, (Jakarta: PT. Ichtiar Baru Van Hoeve, 2006), hlm. 248

${ }^{19}$ Muhammad Dhumhana, Hukum Perbankan di Indonesia, (Bandung:PT.Citra Aditya Bakti, 1993), hlm. 233 berdasarkan prinsip syariah. ${ }^{20}$ Jaminan dalam hukum positif mempunyai kedudukan sebagai pemberi kepastian hukum kepada kreditur atas pengembalian modal/pinjaman/kredit yang ia berikan kepada debitur, dalam arti bahwa barang jaminan setiap waktu tersedia untuk dieksekusi, bila perlu dapat diuangkan untuk melunasi hutang debitur. Nilai jaminan harus lebih tinggi dari jumlah modal/pinjaman/kredit, dengan harapan ketika terjadi wanprestasi atau kredit macet maka jaminan itu dapat menutup (mengcover) pinjaman yang kreditur berikan. ${ }^{21}$

Landasan dibolehkan dhaman terdapat didalam al-Qur'an. Allah berfirman:

"dan siapa yang dapat
mengembalikannya akan
memperoleh bahan makanan
(seberat) beban unta dan aku
menjamin terhadapnya" (QS. Yusuf
:72)

Kemudian dari Hadis Rasulullah saw:

"pinjaman hendaklah dikembalikan dan orang yang menjamin hendaklah membayar" (HR. "Abu Daud dan Tirmidzi)

Para ulama membolehkan dhaman dalam muamalah, karena dhaman diperlukannya dalam waktu-waktu tertentu. Seperti seseorang yang

\footnotetext{
${ }^{20}$ Dewi Nurul Masjtari, Penyelesaian Sengketa dalam Praktik Perbankan Syariah, (Yogyakarta:PT. Gramedia Pustaka Utama, 1995), hlm. 92

${ }^{21}$ Dewi Nurul Masjtari, Penyelesaian ..., hlm.
} 
membutuhkan modal usaha, dapat memperoleh modal tersebut dengan jaminan dari orang yang dipercaya. Para ulama juga membolehkan dhaman, apabila rukun dan syaratnya terpenuhi. Rukun dan syarat tersebut adalah:

a. Orang yang menjamin (dhamin). Dhamin disyaratkan sudah baligh, berakal, merdeka dan cakap bertindak hukum, sehingga dapat mengelola hartanya dan atas kehendak sendiri.

b. Orang yang berpiutang atau orang yang menerima jaminan (madhmunlah). Syaratnya adalah ia harus diketahui dan dikenal oleh dhamin.

c. Orang yang berutang atau orang yang dijamin (madhmun anhu).

d. Objek jaminan utang (madhmun), berupa barang, uang atau orang. Disyaratkan bahwa objek ini harus diketahui dan telah ditetapkan keberadaannya. Apabila belum jelas dan tidak diketahui maka didalamnya terdapat unsur gharar (tipuan).

e. Pernyataan yang dilafalkan oleh dhamin (sighah). Sighah disyaratkan harus dimaksudkan dan mengandung makna jaminan. Seperti perkataan dhamin : "saya menjamin utangmu kepada si A" atau "saya bertanggungjawab membawa si A ke pengadilan”. Dalam hal ini tidak perlu ada jawaban (ijab-Qabul), karena sighah dalam dhaman adalah pernyataan sepihak. ${ }^{22}$

Kedudukan jaminan atau collateral bagi pembiayaan memiliki karakteristik khusus. Tidak semua properti atau harta dapat dijadikan jaminan pembiayaan, melainkan harus memenuhi unsur MAST, yaitu:

a. Marketability yakni adanya pasar yang cukup luas bagi jaminan sehingga tidak sampai melakukan banting harga.

b. Ascertainably of value yakni jaminan harus memiliki standar harga tertentu.

c. Stability of value yakni harta yang dijadikan jaminan stabil dalam harga atau tidak menurun nilainya.

d. Transferability yakni harta yang dijaminkan mudah dipindah tangankan baik secara fisik maupun yuridis.

e. Secured yakni barang yang dijaminkan dapat diadakan pengikatan secara yuridis formal sesuai dengan hukum dan perundang-undangan yang berlaku apabila apabila terjadi wanprestasi. ${ }^{23}$

Selanjutnya jaminan akan diikat dengan hukum pengikatan. Hal ini mengacu pada surat edaran Bank

\footnotetext{
${ }^{22}$ Habib Nazir, Muhammad Hasanuddin, Ensiklopedi ..., hlm. 145

${ }^{23}$ Budi Untung, Kredit Perbankan di Indonesia, (Yogyakarta: Andi), hlm. 58
} 
Indonesia (SE-BI) No.4/248/UPPK/PK tanggal 16 Maret 1972 disebutkan untuk benda yang tidak bergerak memakai lembaga jaminan hak tanggungan dan fiducia. Dimana hak tanggungan dibebankan pada tanah dan bangunan yang ditegaskan dalam pasal 51dan 57 Undang-Undang No.5 tahun 1960 tentang peraturan dasar pokok anggaran atau lebih populer dikenal dengan Undang-Undang pokok agraria (UUPA) yang menjelaskan bahwa hak tanggungan dapat dibebankan pada tanah dengan Hak Milik, Hak Guna Bangunan dan Hak Guna Tanah. Sedangkan untuk fiducia dibebankan pada benda bergerak. ${ }^{24}$

\section{Pendapat Imam Mazhab Tentang Jaminan (Dhaman)}

Para imam mazhab sepakat tentang bolehnya dhaman (jaminan akan memenuhi sesuatu yang ditanggung orang lain). Ha orang yang dijamin yang masih hidup tidak berpindah kepada penjamin karena penjaminan tersebut. Utang tetap dalam tanggungan orang yang dijamin dan tanggungan tersebut tidak menjadi gugur kecuali telah dibayar. Ibn Abi Laila, Ibn Syubramah, Abu tsawr dan Dawud berpendapa utang menjadi gugur. $^{25}$

${ }^{24}$ Sutarno, Aspek...., hlm. 151-152

${ }^{25}$ Syaikh "Allamah Muhammad bin 'Abdurrahman ad-Dimasyqi, Fiqh Empat Mazhab, (Bandung: Hasyimi), hlm.. 248
Menurut pendapat Hanafi, Maliki dan Syafi'i utang tidak lepas dari tanggungan seseorang yang meninggal jika dijanjikan oleh orang lain untuk membayarnya sebagaimana ketika ia masih hidup.

Menurut pendapat Maliki, Syafi'i, Hambali, Abu Yusuf dan Muhammad bin al-Hasan, apabila seseorang meninggal dunia dan ia mempunyai hutang tetapi tidak meninggalkan harta untuk membayarnya boleh menjamin utang orang tersebut, sedangkan menurut Hanafi apabila tidak ditinggalkan harta pembayarannya tidak sah. ${ }^{26}$

Menurut Maliki, Syafi'i dan Hambal, sah jaminan akan membayar tanpa diterima penjaminan itu oleh yang menuntut. Sedangkan menurut Hanafi, tidak sah kecuali pada suatu tempat saja yaitu apabila orang sakit berkata kepada sebagian ahli warisnya, "tanggunglah hutangku". Kemudian utang itu ditanggung sedangkan para pemberi utang tidak hadir. Namun, kalau dalam keadaan sehat ia berbuat demikian, maka penjamin tidak dikenai kewajiban apapun.

Menjamin badan disahkan oleh syara' terhadap setiap orang yang wajib datang ke majelis hukum. Demikian menurut kesepatan pendapat para imam

${ }^{26}$ Ibid, 
mazhab, sah juga menjamin dengan badan mayat agar didatangkan untuk dijadikan kesaksian. Penjamin itu terlepas dari beban jaminan karena telah menyerahkan jaminan tersebut di tempat yang disyaratkan, baik disukai penerima hak maupun tidak. Demikian menurut kesepakatan pendapat para imam mazhab.

Apabila penjamin meninggal sebelum ia menunaikan jaminannya, maka jaminannya batal. Namun, pendapat Maliki tidak membatalkannya. Adapun jika orang yang dijamin melarikan diri maka penjamin tidak dikenai kewajiban apa pun selain dihharuskan mendatangkan orang yang dijamin yang telah lari itu. Jika tidak dapat didatangkan, ia pun tidak dikenai pembayar. Demikian pendapat Hanafi dan Syafi'i. Adapun apabila harta orang yang lari tersebut sulit didatangkan karena sudah lari terlalu jauh, maka diberikan tempo selama waktu yang cukup untuk pergi dan membawanya kembali. Jika ia tidak mampu mendatangkannya, ia boleh dipenjarakan hingga orang yang lari tersebut dapat didatangkan. Demikian pendapat Hanafi. ${ }^{27}$

Maliki dan Hambali berpendapat jika ia tidak dapat mendatangkannya, maka ia dikenai kewajiban membayar harta . menurut pendapat Syafi'i tidak dikenai kewajiban membayar harta sama sekali. Apabila tdak diketahui tempat larinya, tidak perlu dicari. Demikian kesepakatan para imam mazhab, jika seseorang berkata, "jika aku tidak dapat membawanya besok maka aku akan menjamin segala utangnya", lalu ternyata ia tidak dapat mendatangkan atau orang yang dicari itu meninggal, maka ia wajib menjamin segala utang orang yang dijaminnya itu. Demikian pendapat Syafi'i dan Maliki.

Apabila seseorang yang menuduh orang lain bahwa ia mempunyai utang seratus dirham, lalu ada orang lain mengatakan,"jika besok ia tidak dapat membayar aku yang akan membayarnya" maka ia wajib membayarnya orang yang dituduh itu tidak membayar. Demikian pendapat Syafi'i, Maliki dan Muhammad bin alHasan. $^{28}$

Menjamin segala beban yang terjadi dalam jual-beli hukumnya boleh, demikian pendapat Hanafi, Maliki dan Hambali. Apaun pendapat Syafi'i yang paling kuat: boleh jika sesudah diterima uang atau harga. Semua orang yang berada di seluruh daerah, tentu tidak sama dengannya, karenanya hal 
demikian tidak boleh sebab ia merupakan jaminan yang tidak wajib. ${ }^{29}$

\section{Urgensi Jaminan Pada Pembiayaan Perbankan Syariah}

Dalam menjalankan operasional pembiayaannya bank syariah memiliki perbedaan yang sangat prinsipil dengan bank konvensional. Pada bank konvensional, penyaluran kredit tidak dibedakan antara konsumtif dan produktif, apalagi perbedaan akad sehingga semua penyaluran kredit pada bank konvensional menggunakan manajemen risiko yang sama demikian juga sistem pengambilan keuntungannya juga menggunakan sistem yang sama yaitu pengambilan keuntungan melalui bunga (interest). Manajemen bank tidak terlalu menghabiskan energi untuk membuat standard operating procedure terhadap masing-masing pembiayaan, karena perlakuan kredit pada bank konvensional hanya satu saja, karena kredit tersebut merupakan hutang yang harus dibayar oleh debitur dalam jumlah tertentu sesuai dengan kesepakatan yang telah dibuat di awal kontrak. Dengan perjanjian kredit seperti tersebut pihak bank tidak perlu meneliti dan menganalisis tujuan permohonan kredit yang diajukan oleh pemohon, atau kelaikan usaha dan hal-hal lain yang berkaitan dengan kredit usaha

${ }^{29}$ Ibid, hlm. 249-250 atau kredit produktif, karena yang dibutuhkan oleh bank hanya sistem penjaminannya.

Pada bank syariah unsur riba, gharar dan tadlis harus dihilangkan dan operasionalnya disesuaikan dengan konsep fikih, bahwa hal-hal yang dilarang dalam transaksi bisnis seperti riba, tadlis dan gharar jelas keharamannya. Bank syariah di Indonesia menjadi salah satu institusi yang eksis dalam masyarakat harus menghindari unsur riba dalam sistemnya maupun operasionalnya, apalagi menggunakan sistem pengambilan keuntungan dengan cara interest, meskipun masih terjadi debat di kalangan pemikir hukum Islam.

Diversifikasi model pembiayaan dapat dilakukan oleh bank syariah selama tetap berpegang pada prinsipprinsip kehalalan transaksi keuangan, barang dan jasa. Dengan pola transaksi berbeda-beda bank syariah dituntut kehandalan dalam membuat role mode untuk setiap sistem operasional sebagai bentuk implementasi dari akad yang disepakati antara bank dengan debiturnya.

Kemampuan internal manajemen bank dalam menilai feasibilitas suatu usaha untuk dibiayai menjadi langkah awal untuk memprediksi 
kualitas suatu usaha tersebut mampu mendatangkan keuntungan atau tidak bagi bank syariah. Tidak semua nasabah debitur memiliki kemampuan mengelola usaha, sehingga bila penilaian dan analisi yang dilakukan oleh manajemen bank syariah tidak tepat maka memungkinnya terbuka peluang terjadinya NPF bagi bank. Namun tidak semua nasabah debitur menepati akad yang telah dibuat untuk membayar kembali pembiayaan yang telah diberikan kepadanya beserta keuntungan yang menjadi hak bank syariah. Sehingga bank syariah harus hati-hati terhadap berbagai kemungkinan, sehingga cara praktis penanggulangannya melalui sistem penjaminan dan agunan tambahan yang ditetapkan oleh manajemen bank syariah pada awal akad.

$$
\text { Perjanjian penyaluran }
$$

pembiayaan pada bank syariah tetap dengan mengedepankan prinsip tata kelola yang baik, mencakup prinsip transparansi, akuntabilitas, pertanggungjawaban, profesional dan menerapkan prinsip kehati- hatian bank dalam penyaluran dananya sebagaimana ketentuan UU No. 21 Tahun 2008 Pasal 34 dan Pasal 35. Adapun bunyi Pasal 34 ayat (1) yaitu:

"Bank syariah dan UUS wajib menerapkan tata kelola yang baik yang mencakup prinsip transparansi, akuntabilitas, pertanggungjawaban, profesional dan kewajaran dalam menjalankan kegiatannya."

Bank syariah tidak mungkin menanggung risiko yang dilakukan oleh nasabah debiturnya, karena bank syariah sebagai pengelola dana tabungan dan deposito berposisi sebagai mudharib dalam akad mudarabah paralel harus mampu mempertanggungjawabkan semua dana nasabah krediturnya. Langkah-langkah pengamanan penyaluran pembiayaan pada bank syari'ah ditetapkan sesuai ketentuan yuridis formal yang ditetapkan oleh pemerintah Indonesia, karena pemerintah sebagai penjamin tabungan masyarakat pada bank-bank yang beroperasi di Indonesia memiliki kepentingan untuk menjaga stabilitas ekonomi. Bahkan pemerintah juga menetapkan ketentuan pengelolaan keuangan yang sehat pada perbankan agar tidak terjadi pengemplengan dana masyarakat oleh manajemen bank umum karena banyak juga manajemen bank yang mengunakan dana masyarakat untuk kepentingan pribadi, seperti kasus terbaru terjadi di Bank Surabaya, direktur utamanya melarikan dana nasabah.

Risiko yang dihadapi bank syariah dari penyaluran pembiayaan musyarakah dan mudarabah sangat 
besar karena pembiayaan NUCC ini sepenuhnya tergantung dari mekanisme pasar dan kehandalan nasabah debitur dalam mengelola investasi. Faktor risiko inilah yang menyebabkan bank syariah sangat hatihati dan membatasi jumlah dana yang bisa dikucurkan untuk pembiayaan NUCC baik musyarakah maupun mudarabah. Bank syariah juga protektif dalam melakukan investasi untuk pembiayaan ini, sehingga semua pembiayaan bank syariah yang diklasifikasikan sebagai pembiayaan natural un-certainty contract dilakukan dalam relatif singkat (short term investment).

$$
\text { Jaminan sebagai ukuran }
$$

kemampuan kekayaan yang dimiliki nasabah debitur dapat menjadi salah satu bentuk keyakinan bank. Dengan jaminan pada pembiayaan musyarakah dan mudarabah bank syariah memperoleh keyakinan terhadap kemampuan finansial nasabah debiturnya. Baik kemampuan nasabah debitur untuk menghadirkan jaminan dalam bentuk cash collateral maupun agunan dalam bentuk fidusia dan hak tanggungan.

Pada Pasal 1 ayat (26) UU No 21 Tahun 2008 pemerintah menegaskan kembali bahwa jaminan dari nasabah debitur urgen bagi bank syariah. Jaminan yang dibutuhkan oleh bank bisa dalam bentuk jaminan pokok maupun jaminan tambahan. Bila bank tidak memiliki jaminan apa-apa dari nasabah debiturnya maka bank tidak dapat menagih hak nya ketika nasabah debitur melakukan salah satu tindakan moral hazard yang mengakibatkan NPF bagi bank syariah, bahkan bisa saja nasabah debitur melarikan diri sehingga bank tidak memiliki aset untuk menuntut penunaian kewajiban debiturnya.

Dalam Pasal 23 UU No. 21 Tahun 2008, pada ayat (2) dijelaskan lebih lanjut tentang prosedur pengucuran pembiayaan, jaminan perlu dikuasai oleh bank dan dinilai untuk mengukur kemampuan nasabah debiturnya, bank bukan hanya menilai jaminan saja karena beberapa aspek lain yang terkait dengan pembiayaan perlu dinilai seperti modal dan prosepek usaha. ${ }^{30}$

\section{DENDA}

\section{Sanksi Denda}

Dalam Kamus Besar Bahasa Indonesia disebutkan bahwa sanksi (hukum) memiliki arti, diantaranya:

a. Imbalan negatif, berupa pembebanan atau penderitaan yang ditentukan di hukum; dan

${ }^{30}$ Muhammad Maulana, "Jaminan dalam Pembiayaan Pada Perbankan Syariah", Islam Futura, Vol.14, No.1, Agustus 2014, hlm. 83-85 
b. Imbalan positif, yang berupa hadiah atau anugerah yang ditentukan di hukum.

Sedangkan denda memiliki arti hukuman yang berupa keharusan membayar dalam bentuk uang (karena melanggar aturan, undang-undang dan sebagainya). Jadi, sanksi memiliki arti imbalan negatif ketika dikait dengan denda, sehingga kita dapat memahami sanksi denda sebagai suatu imbalan negatif berupa pembebanan keharusan pembayaran dalam bentuk uang.

Di Indonesia, secara umum dikenal sekurang-kurangnya tiga jenis sanksi yaitu:

a. Sanksi hukum pidana;

b. Sanksi hukum perdata; dan

c. Sanksi administrasi/administratif.

Sanksi denda termasuk dalam sanksi administrasi/administratif. Secara khusus, untuk pelanggaran UndangUndang negara, sanksi denda diatur dalam Peraturan Pemerintah No.28 Tahun 2008 tentang Pengenaan Sanksi Administrasi berupa denda di Bidang Kepabeanan.

Dalam syariah khsusunya ekonomi syariah dikenal setidaknya dua bentuk sanksi denda yaitu denda ta'zir dan denda ta'widh. Dalam kegiatan perbankan syariah khususnya di Indonesia, kedua bentuk sanksi denda tersebut diatur dan dikenal sebagai suatu solusi permasalahan pembiayaan yang dikenakan pada nasabah wanprestasi atas tidakan pelanggarannya terhadap kontrak atau akad yang telah disetujui.

\section{Pengertian Denda (Ta'zir)}

Denda ta'zir atau sebagian menyebutnya Late Charge. ${ }^{31}$ Denda dalam konteks akad disebut garamah atau ta'zir. Denda adalah hukuman yang berupa materi atau benda dikenakan dan harus dibayarkan oleh pelanggarnya. ${ }^{32}$ Menurut Aliminsyah, denda (fine) diartikan sebagai hukuman berupa uang yang harus dibayarkan karena melanggar peraturan atau undangundang. Adapun denda bunga adalah bunga atau tambahan bunga karena melanggar suatu ketentuan keterlambatan, pelunasan utang pokok atau ketentuan rasio kas. ${ }^{33}$

Pinalti hukuman berupa pesanan biaya hutang pelanggaran suatu perjanjian, misalnya kelambatan pelunasan utang pokok, atau pelanggaran rasio kas. Adapun pinalti klause adalah klausal denda atau perjanjian pinjam-meminjam intrumen tabungan mengenai pengenaan denda

\footnotetext{
${ }^{31}$ Divisi Pengembangan Produk dan Edukasi Departemen Perbankan Syarian Otoritas Jasa Keuangan, Standar Produk Perbankan Syariah Murabahah, hlm 18

${ }^{32}$ Daryanto, Bahasa Kamus Indonesia Lengkap, (Surabaya: Penerbit APOLLO, 1997), hlm. 23

${ }^{33}$ Aliminsyah dan Padji, Kamus Istilah Keuangan dan Perbankan, Yrama Widya, hlm. 339
} 
bila ketentuan kontrak tidak dipenuhi, pembayaran kembali pinjaman tertunda atau penarikan tabungan sebelum jatuh tempo. ${ }^{34}$

Denda adalah bentuk hukuman yang melibatkan uang yang harus dibayarkan dalam jumlah tertentu. Jenis yang paling umum adalah uang denda yang jumlahnya tetap dan denda harian yang dibayarkan menurut penghasilan seseorang.

Denda merupakan salah satu jenis dari hukuman ta'zir. Ta'zir menurut bahasa adalah ta'dib, artinya memberi pelajaran. Ta'zir juga diartikan dengan Ar-Raddu Wal Man'u, yang artinya menolak dan mencegah. At-ta'zir adalah larangan, pencegahan, menegur, menghukum, mencela dan memukul. Hukuman yang tidak ditentukan (bentuk dan jumlahnya), yang wajib dilaksanakan terhadap segala bentuk maksiat yang tidak termasuk hudud dan kafarat, baik pelanggaran itu menyangkut hak Allah SWT maupun hak pribadi.

Menurut wahbah Al-Zuhaili dalam kitab Al-Fiqh Al-Islami wa Adillatuh, sanksi-sanksi ta'zir adalah hukum-hukuman yang secara adalah hukum-hukuman yang secara syara' tidak ditegaskan mengenai ukurannya.

\footnotetext{
${ }^{34}$ Sujana Ismaya, Kamus Perbankan, dilengkapi dengan daftar nama mata uang dan UU bank Tahun 2004
}

Syariat Islam menyerahkannya kepada penguasa negara untuk menentukan sanksi terhadap pelaku tindak pidana yang sesuai dengan kejahatannya. Selain itu menumpas permusuhan, mewujudkan situasi aman terendali dan perbaikan, serta melindungi masyarakat kapan saja dan dimana saja. Sanksisanksi ta'zir ini sangat beragam sesuai dengan situasi dan kondisi masyarakat, taraf pendidikan masyarkat dan berbagai keadaan lain manusia dalam berbagai masa dan tempat. ${ }^{35}$

Dikarenakan ta'zir tidak ditentukan secara langsung oleh AlQur'an dan Hadis, maka ini menjadi kompensasi penguasa setempat. Dalam memutuskn jenis dan ukuran sanksi ta'zir, harus tetap memberikan petunjuk nash secara teliti karena menyangkut kemaslahatan umum. ${ }^{36}$

Nilai atau besaran denda yang dikenakan terhadap nasabah diserahkan kepada masing-masing LKS dengan dasar kesepakatan antara nasabah dan LKS saat akad ditandatangani. Denda yang diterima oleh LKS selanjutnya dimasukkan dan diakui sebagai dana sosial dalam pembukuan LKS tersebut dan tidak dapat dikaui sebagai laba. Dana sosial tersebut nantunya dapat disalurkan oleh bank kepada masyarakat

${ }^{35}$ M.Nurul Irfan dan Masyofah, Fiqh Jinayah, (Jakarta: AMZAH, 2013), hlm. 139

${ }^{36}$ Ibid, hlm. 140 
dengan tujuan sosial baik dalam bentuk bantuan atau lainnya.

Kegiatan pembiayaan merupakan proses pembentukan asset bank, akan tetapi memiliki risk asset bagi bank karena asset bank ini dikuasai oleh pihak luar bank yakni nasabah atau debitur. Risiko dapat berupa pembiayaan tidak dapat dikembalikan tepat pada waktunya atau yang sering disebut Non Performing Loan (NPL). Mengenai pembiayaan bermasalah ini, Bank Indonesia melalui Surat Keputusan Direksi Bank Indonesia No.31/147/KEP/DIR tanggal 12 November 1998 memberikan penggolongan mengenai kualitas kredit, yang diantaranya : Lancar; dalam perhatian khusus; kurang lancar; diragukan dan macet. ${ }^{37}$ Banyak penyebab pembiayaan bermasalah misalnya karena debitur tidak mampu atau karena mengalami kemerosotan usaha dan gagalnya usaha yang mengakibatkan berkurangnya pendapatan usaha debitur atau memang debitur sengaja tidak mau membayar.

Sedangkan denda ta'widh atau ganti rugi adalah menutup kerugian yang terjadi akibat pelanggaran atau kekeliruan. OJK mendefinisikan ta'widh sebagai penggantian terhadap biaya-biaya yang dikeluarkan oleh bank

${ }^{37}$ Ibid., hlm. 263 dalam proses memperoleh pembayaran dari nasabah akibat penyimpangan yang dilakukan oleh nasabah (wanprestasi), termasuk namun tidak terbatas pada saat nasabah menunggak pembayaran angsuran. Perolehan ta'widh akan diakui sebagai pendapatan dalam pembukuan Bank. ${ }^{38}$

Begtu juga dengan denda ta'zir, denda ta'widh hanya boleh dikenakan bagi nasabah yang sengaja atau karena kelalaian menunda pembayaran kewajibannya. Pengenaiaan ta'widh didasarkan pada kerugian riil yang dapat diperhitungkan dengan jelas yang dialami oleh LKS. Besar ganti rugi yang dapat dikenakan pada nasabah sesuai dengn nilai kerugian riil (real loss) yang pasti dialami (fixwd cost) berupa biayabiaya riil yang dikeluarkan dalam rangka penagihan hak bank. Kerugian yang diperkirakan akan terjadi (potential loss) karena adanya peluang yang hilang (potential loss) tidak dapat dimasukkan dalam besaran ganti rugi.

\section{Fatwa No.17/DSN-MUI/IX/2000}

Berdasarkan Fatwa Dewan Syariah Nasional No.17/DSNMUI/IX/2000, terdapat beberapa poin yang menjadi acuan pengenaan denda kepada nasabah Bank Syariah, yaitu:

\footnotetext{
${ }^{38}$ Divisi Pengembangan Produk dan Edukasi Departemen Perbankan Syarian Otoritas Jasa Keuangan, Standar..., hlm. 18
} 
a. Sanksi denda dapat dikenakan kepada nasabah yang mampu membayar angsuran namun menunda-nunda pembayaran serta tidak memiliki itikad baik untuk membayar utangnya, akan tetapi tidak dikenakan sanksi ini kepada nasabah yang tidak atau belum mampu membayar disebabkan oleh forse majeur.

b. Sanksi didasarkan pada prinsip ta'zir yang bertujuan agar nasabah lebih disiplin dalam melaksanakan kewajibannya.

c. Sanksi dapat berupa denda sejumlah uang yang besarnya ditentukan atas dasar kesepakatan dan dibuat saat akad ditandatangani.

d. Dana yang berasal dari denda diperuntukan sebagai dana sosial.

Dari poin-poin di atas, jelas bahwa Bank Syariah dapat mengenakan denda kepada nasabah yang terlambat melakukan pembayaran angsuran atau "tidak disiplin" karena melakukan pelunasan dipercepat. Denda tersebut bertujuan agar nasabah lebih disiplin melaksanakan kewajibannya. Besarnya denda yang akan dibayarkan telah disepakati sejak awal akad, yang mana dalam bentuk rupiah bukan persentase atas nilai angsuran bahkan tidak bergantung atas lamanya keterlambatan.
4. Tujuan dan Syarat-Syarat Sanksi Ta'zir

Di bawah ini tujuan dari diberlakukannya sanksi ta'zir, yaitu sebagai berikut: ${ }^{39}$

a. Prefentif (pencegahan), ditujukan bagi orang lain yang belum melakukan jarimah.

b. Represif (membuat pelaku jera), dimaksudkan agar pelaku tidak mengulangi perbuatan jarimah di kemudian hari.

c. Kuratif, ta'zir harus mampu membawa perbaikan perilaku terpidana di kemudian hari.

d. Edukatif (pendidikan), diharapkan dapat mengubah pola hidupnya ke arah yang lebih baik.

Syara' tidak menentukan macammacam hukuman untuk setiap jarimah ta'zir, tetapi menyebutkan sekumpulan hukuman, dari yang paling ringan sampai yang paling berat. Hakim diberi kebebasan untuk memilih hukuman mana yang sesuai. Dengan demikian, sanksi ta'zir tidak mempunyai batas tertentu.

Ta'zir berlaku atas semua orang yang melakukan kejahatan. Syaratnya adalah berakal sehat. Tidak ada perbedaan, baik laki-laki maupun perempuan, dewasa maupun anak-anak, atau kafir maupun muslim. Setiap orang yang melakukan kemungkaran atau

${ }^{39}$ Ibid, hlm. 142 
pengganggu pihak lain dengan alasan yang tidak dibenarkan, baik dengan perbuatan, ucapan atau isyarat, perlu diberi sanksi ta'zir agar tidak mengulangi perbuatannya. ${ }^{40}$

Yang menjadi perbedaan utama denda pada Bank Syariah dan Bank Konvensional adalah denda yang dibayarkan oleh nasabah tidak dicatat dalam pos pendapatan, melainkan dalam pembukuan lain di luar neraca dan laba rugi Bank Syariah. Dana yang berasal dari denda diperuntukkan sebagai dana sosial dimana dana tersebut wajib dilaporkan dalam laporan keuangan publikasi Bank Syariah yang terbit setiap triwulan.

Sedangkan tindakan Bank Syariah pada nasabah yang terlambat membayar karena nasabah tidak mampu akan tetapi kooperatif (beriktikad baik) dalam usaha menyelesaikan pembiayaan bermasalah, maka ada dua strategi yang dapat ditempuh, yaitu:

a. Penyelamatan pembiayaan yakni langkah penyelesaian pembiayaan melalui perundingan kembali antara kreditur dan debitur dengan memperingan syarat-syarat pengembalian yang diharapkan nasabah mampu untuk menyelesaikan pembiayaan itu. Penyelesaian dengan tahap ini dinamakan restrukturisasi kredit (pembiayaan). Dalam langkah ini menurut Keputusan Direksi Bank Indonesia fasilitas dan kebijakan yang dilakukan adalah :

1) Penurunan suku bunga kredit

2) Pengurangan tunggakan bunga kredit

3) Pengurangan tunggakan pokok kredit

4) Perpanjangan jangka waktu kredit

5) Penambahan fasilitas kredit

6) Pengambil alihan anggunan atau aset debitur

7) Jaminan kredit dibeli oleh bank

8) Konversi kredit menjadi modal sementara dan pemilikan saham.

9) Alih manajemen

10) Pengambil alihan pengelolaan proyek

11) Subrogasi

12) Debitur menjual sendiri barang jaminan

13) Bank menjual barang jaminan di bawah tangan berdasarkan surat kuasa

14) Penghapusan piutang

15) Cegah tangkal (CEKAL) debitur macet. $^{41}$

b. Penyelesaian pembiayaan melalui lembaga hukum seperti Pengadilan atau Diretorat Jendral Piutang dan 
Lelang Negara atau badan lainnya.

Tujuan penyelesaian pembiayaan ini adalah untuk menjual atau mengeksekusi benda jaminan. ${ }^{42}$

\section{E. KEDUDUKAN JAMINAN DAN DENDA PADA PEMBIAYAAN BANK SYARIAH}

Adanya jaminan dan denda pada pembiayaan di bank Syariah dilatar belakangi banyak kegiatan pembiayaan yang tidak berjalan lancar dikarenakan nasabah tidak mampu memenuhi kewajibannya pada bank. Untuk mencegah hal tersebut, bank Syariah wajib melaksanakan sistem kehati-hatian dengan menyertakan jaminan yang merupakan esensi yang harus ada bagi nasabah penerima fasilitas yang mengajukan pembiayaan agar bank mendapat kepastian dan guna menjamin pelunasan kewajiban nasabah penerima fasilitas, akan tetapi apabila nasabah mampu tidak memenuhi kewajibannya pada bank maka tindakan awal bank adalah memberikan beban denda pada nasabah.

Sesuai dengan fatwa DSN No.7 tentang jaminan, bahwa: "jaminan hanya dapat dicairkan apabila nasabah melakukan kesalahan yang disengaja, lalai dan menyalahi perjanjian". ${ }^{43}$ Artinya adalah jaminan dalam perbankan syariah hanya dijadikan sebagai alternative terakhir

${ }^{42}$ Ibid., hlm.265-266

${ }^{43}$ Euis Amalia, M.Taufiqi dan Dwi Nuraini I, Konsep dan Mekanisme Bank Syariah, FSSh UIN Syahid Jakarta: 2007, hlm. 29 setelah meyakini bahwa usaha nasabah dianggap tidak bisa ditolong atau diselamatkan, sehingga jaminan menjadi alternative terakhir bank untuk mendapatkan pengembalian modal yang telah dicairkan dalam pembiayaan kepada nasabah

Denda merupakan sanksi yang diperuntukan untuk nasabah yang dengan sengaja menunda pembayaran pembiayaan padahal nasabah tersebut mampu. Berdasarkan Fatwa No.17/DSNMUI/IX/2000 ini dijelaskan bahwa denda ini didasarkan pada prinsip ta'zir yang bertujuan agar nasabah lebih disiplin dalam melaksanakan kewajibannya dan dana yang berasal dari denda diperuntukan sebagai dana sosial bukan sebagai pendapatan bank. Akan tetapi, perlakuan yang diberikan pada nasabah yang tidak mampu untuk melaksanakan kewajibannya yang disebabkan oleh merosotnya usaha nasabah adalah dengan dua strategi yaitu penyelamatan pembiayaan dengan restrukturisasi selanjutnya bila tidak dapat menyelasaikannya maka dapat dilakukan penyelesaian pembiayaan dengan melakukan tindakan eksekusi anggunan.

\section{F. KESIMPULAN}

Dari pemaparan diatas dapat disimpulkan bahwa kedudukan jaminan pada bank syariah adalah sebagai penerapan prinsip kehati-hatian bank atau prudential banking dan kedudukan denda 
pada bank syariah adalah didasarkan pada prinsip ta'zir yang bertujuan agar nasabah lebih disiplin dalam melaksanakan kewajibannya. Dana yang berasal dari denda ini diperuntukan untuk dana sosial.

\section{DAFTAR PUSTAKA}

Aliminsyah., Padji, Kamus Istilah Keuangan dan Perbankan, Yrama Widya

Bank Indonesia, 1999, Kamus Perbankan, Cet ke-1

Dahlan, Abdul Aziz., 2006, Ensiklopedi Hukum Islam, Jakarta: PT. Ichtiar Baru Van Hoeve

Dahlan, Ahmad., 2012, Bank Syariah Teoritik Praktik Kritik, Yogyakarta:Teras

Daryanto, 1997, Bahasa Kamus Indonesia Lengkap, Surabaya: Penerbit APOLLO

Dhumhana, Muhammad., 1993, Hukum Perbankan di Indonesia, Bandung:PT.Citra Aditya Bakti

Departemen Agama RI, 2008, UndangUndang Republik Indonesia Nomor 21 Tahun 2008 Tentang Perbankan Syariah, Jakarta

Dewi, Gemala., 2007, Aspek-Aspek Hukum dalam Perbankan dan Perasuransian Syariah di Indonesia, Cet.IV, Jakarta:Kencana

Haroen, Nasrun., 2007, Fiqh Muamalah, Jakarta: Gaya Media Pratama

Hermansyah., 2005, Hukum Perbankan Nasional Indonesia, Jakarta:Kencana

Irfan, M.Nurul., Masyofah., 2013, Fiqh Jinayah, Jakarta: AMZAH

Ismaya, Sujana., Kamus Perbankan, dilengkapi dengan daftar nama mata uang dan UU bank Tahun 2004

Kasmir., 2008, Bank dan Lembaga Keuangan lainnya. Edisi Revisi,
Jakarta: PT.Raja Grafindo Persada, 2008)

Masjtari, Dewi Nurul., 1995, Penyelesaian Sengketa dalam Praktik Perbankan Syariah, Yogyakarta:PT. Gramedia Pustaka Utama

Maulana, Muhammad., 2014, "Jaminan dalam Pembiayaan Pada Perbankan Syariah”, Islam Futura, Vol.14, No.1, Agustus 2014

Muhammad, 2005, Manajemen Pembiayaan Bank Syariah, Yogyakarat: UPP AMP YKPN

MUI, 2014, Himpunan Fatwa Keuangan Syariah Dewan Syariah Nasional MUI, Jakarta: Erlangga

Nazir, Habib., Muhammad Hasanuddin., 2008, Ensiklopedi Ekonomi dan Perbankan Syariah, Bandung: Kafa Publishing

Nuraini, Dwi., dkk., 2007, Konsep dan Mekanisme Bank Syariah, FSSh UIN Syahid Jakarta

Sholihin, Ahmad Ifham., 2010, Buku Pintar Ekonomi Syariah, Jakarta: PT.Gramedia Pustaka Utama

Sinungun, Muchdarsyah., 2000, Manajemen Dana Bank ed II, Jakarta:PT.Bumi Aksara

Sutarno., 2005, Aspek-Aspek Hukum Perkreditan Pada Bank, Bandung: Alfabeta

Untung, Budi., Kredit Perbankan di Indonesia, Yogyakarta: Andi

Zulkifli, Sunarto., 2003, Panduan Praktis Transaksi Perbankan Syariah, Jakarta: Zikrul Hakim 